Fakultas Ekonomi, Universitas Cokroaminoto Yogyakarta

\title{
Pengaruh Brand Image, Kualitas Produk dan Endorsement Selebriti Instagram terhadap Minat Beli Konsumen pada Produk Skin Care MS GLOW
}

\author{
${ }^{1}$ Ulfatul Hasanah, ${ }^{2}$ Eko Giyartiningrum \\ ${ }^{1,2}$ Program Studi Manajemen Fakultas Ekonomi \\ Universitas Cokroaminoto Yogyakarta \\ Email korespondensi: ekogiyarti@gmail.com
}

\begin{abstract}
This study aims to determine the effect of brand image, product quality, celebrity endorsements on Instagram on consumer buying interest in MS GLOW skin care products. Using the survey method, the sample in this study amounted to 100 respondents who were consumers of MS GLOW skin care products. The data analysis technique used multiple linear regression analysis with the SPSS program. Based on the results of multiple linear regression, brand image has a significant effect on consumer buying interest, product quality has a significant effect on consumer buying interest, and celebrity endorsements on Instagram have no significant effect on consumer buying interest.
\end{abstract}

Keywords: Brand Image, Product Quality, Instagram Celebrity Endorsement, Consumer Buying Interest

\section{Latar Belakang Masalah}

Adanya social media Instagram di Indonesia memiliki dampak yang luar biasa terhadap pasar bisnis di Indonesia, sebagai dampak dari kemajuan teknologi yang semakin hari semakin pesat. Instagram ada sebuah aplikasi yang memungkinkan penggunanya untuk berbagi foto ataupun vidio. Penggunaannya yang mudah membuat aplikasi ini begitu diminati oleh bergabai kalangan, baik sekedar membagi informasi terkait kegiatan sehari-hari, maupun untuk berbisnis.

Pemakaian endorsement selebriti istagram dalam suatu iklan sering dilakukan untuk mendukung penjualan suatu produk, terutama pada pruduk kecantian seperti skin care yang sangat erat kaitannya dengan model cantik atau tampan sebagai brand ambassador ataupun endorse. Produk kecantikan seperti halnya skin care sudah begitu marak dipasaran dan semakin banyak persaingan, oleh karenanya pentingnya suatu perusahaan tersebut untuk menginformasikan 


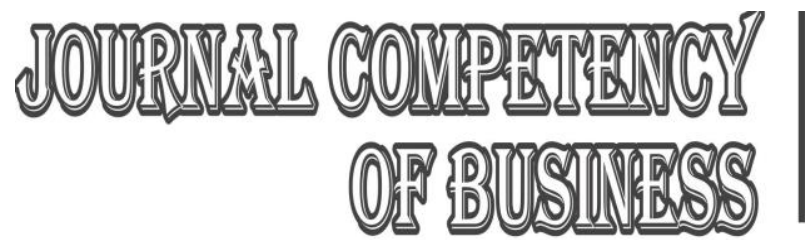

Fakultas Ekonomi, Universitas Cokroaminoto Yogyakarta

produknya kepasaran harus semakin kreatif, menarik dan mudah diingat untuk menarik hati para calon konsumen.

Menurut Schiffman dan Kanuk (2008:78), konsumen cenderung untuk mempercayai produk dengan merek yang disukai ataupun terkenal. Alasan inilah yang mendasari perusahaan untuk memperkuat posisi merknya agar tercipta brand image (citra merek) yang positif dan menancap kuat dalam benak konsumen. Melalui brand image, konsumen mampu mengenali sebuah produk, mengevaluasi kualitas, mengurangi resiko pembelian, dan memperoleh pengalaman dan kepuasan dari diferensiasi produk tertentu Lin dkk (2017:122). Kotler dan Keller (2009:406) menjelaskan bahwa citra merek adalah persepsi dan keyakinan yang dilakukan oleh konsumen, seperti tercermin dalam asosiasi yang terjadi dalam ingatan konsumen.

Dalam penelitian ini mengangkat produk skincare MS GLOW, yang mempromosikan produknya melalui media sosial instagram dengan caraendorsement. Meski terbilang baru dibandingkan dengan produk yang sudah lebih dulu sudah ada di pasaran, tetapi produk skincare MS GLOW sudah banyak dikenal di kalangan masyarakat.

\section{Tinjauan Pustaka dan Pengembangan Hiptesis}

\section{Brand Image}

Brand image adalah anggapan tentang merek yang direfleksikan konsumen yang berpegang pada ingatan konsumen. Cara orang berpikir tentang sebuah merek secara abstrak dalam pemikiran mereka, sekalipun pada saat mereka memikirkannya, mereka tidak berhadapan langsung dengan produk (Keller, 2003:166).

Brand Image merupakan sekumpulan asosiasi yang dipersepsikan oleh konsumen terhadap merek tertentu, yang dikenal dengan istilah brand association. Tiga indikator brand image terkait dengan brand association (Keller, 2013:122) adalah Strength of brand associations yang bergantung pada informasi mengenai merek dalam memori masyarakat dan cara mempertahankannya sebagai bagian dari citra merek produk yang diiklankan. Brand image mirip dengan citra diri 


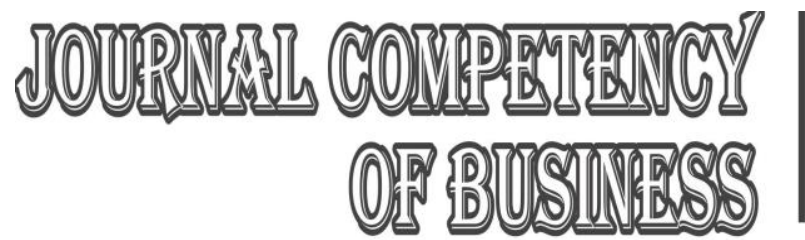

Fakultas Ekonomi, Universitas Cokroaminoto Yogyakarta

konsumen sebagai konsumen mengasosiasikan dirinya dengan merek, dalam lingkungan yang sangat kompetitif ini, citra merek sangat penting untuk menciptakan merek, posisi yang baik perusahaan selalu mampu memainkan perannya. citra merek menunjukan keseluruhan persepsi terhadap merek dan dibentuk dari informasi dan pengalaman masa lalu terhadap merek itu. Menurut Setiadi (2003: 180) citra merek (brand image) merupakan representasi dari keseluruhan persepsi terhadap merek dan dibentuk dari informasi dan pengalaman masa lalu terhadap merek itu. Maka tidak dipungkiri brand image adalah hal penting yang harus diperhatikan perusahaan untuk menciptakan produknya sebagai minat beli konsumen.

\section{Kualitas Produk}

Kualitas suatu produk dapat dinilai berdasarkan sekumpulan kriteria yang berbeda karena mengingat kepentingan dan keterlibatan konsumen berbeda-beda. Menurut Kotler dan Keller (2009:143) "Kualitas adalah totalitas fitur dan karakteristik yang memampukan produk memuaskan kebutuhan yang dinyatakan maupun tidak dinyatakan”. Persepsi terhadap kualitas mencerminkan perasaan konsumen secara menyeluruh mengenai suatu produk.

Ada delapan dimensi kualitas produk, berkaitan dengan penelitian ini tiga diantaranya tidak digunakan yaitu dimensi kehandalan, kesesuaian dan kemudahan perbaikan. Dimensi kehandalan (reliability) adalah hal yang berkaitan dengan probabilitas atau kemungkinan suatu barang berhasil menjalankan fungsinya setiap kali digunakan dalam periode waktu tertentu dan dalam kondisi tertentu, dengan kata lain karakteristik serta unsur dari dimensi kehandalan sudah termasuk dalam dimensi kinerja. Dimensi kesesuaian terhadap standar, unit produk yang dihasilkan identik dan memenuhi spesifikasi yang dijanjikan, berdasarkan pengertian tersebut peneliti menyimpulkan dimensi ini dapat di kategorikan dalam karakteristik kualitas yang dipersepsikan. Sedangkan dimensi kemudahan perbaikan (serviceability) adalah produk tahan lama tidak akan mampu beroperasi penuh tanpa harus dilakukan pemeliharaan ataupun perbaikan secara periodik. Diferensiasi ini menjanjikan mudah tidaknya produk tersebut 


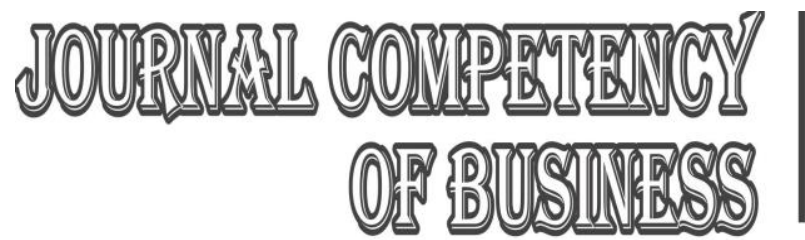

Fakultas Ekonomi, Universitas Cokroaminoto Yogyakarta

diperbaiki. Berdasarkan pengertian diatas dapat diartikan bahwa dimensi ini tidak sesuai jika digunakan dalam pengukuran produk lipstik yang pada dasarnya tidak membutuhkan perbaikan, maka penulis hanya menampilkan lima dimensi dari delapan dimensi pengukuran.

\section{Endorsement selebriti instagram}

Soesatyo dan Rumambi (2013:4) celebrity endorsement adalah penyampaian pesan tentang suatu jenis produk dengan menggunakan orang yang telah terkenal atau kalangan selebritis dengan tujuan untuk mempengaruhi orang lain karena prestasinya. Nilai kepercayaan yang dimanfaatkan oleh para pemasang iklan ialah pendukung yang secara luas dipandang sebagai pendukung yang jujur, dapat dipercaya dan dapat diandalkan (Shimp, 2003:470).Celebrity Endorser sendiri adalah tokoh (aktor, penghibur, atau atlet) yang dikenal masyarakat karena prestasinya di dalam bidang-bidangyang berbeda dari golongan produk yang didukung Shimp (2003:460).

Arora (2013) menyebutkan bahwa penggunaan celebrity endorser akan membuat kepercayaan yang lebih besar, evaluasi yang lebih menguntungkan dari produk dan iklan, dan secara signifikan lebih positif untuk meningkatkan niat beli. Pemakaian celebrity dalam sebuah iklan sering digunakan untuk mendukung penjualan suatu produk, sehingga menimbulkan niat beli konsumen secara tidak langsung. Semakin terkenal celebrity yang menjadi model dari iklan tersebut, maka dapat memunculkan keinginan untuk membeli produk yang sedang didukung oleh celebrity tersebut.

\section{Minat beli}

Minat beli konsumenmenurut Kotler dan Keller (2009:137) adalah perilaku konsumen yang muncul sebagai respon terhadap objek yang menunjukkan keinginan konsumen untuk melakukan pembelian. Terdapat dua faktor eksternal yang mempengaruhi minat beli seseorang. Pertama, sikap orang lain, dalam hal ini sikap orang lain yang berpengaruh pada minat beli tergantung pada dua hal, yaitu besarnya pengaruh sikap negatif seseorang terhadap alternatif 
Fakultas Ekonomi, Universitas Cokroaminoto Yogyakarta

yang diminati oleh konsumen, serta motivasi konsumen untuk terpengaruh dengan orang lain yang berhubungan dengan minat pembeliannya. Kedua, situasi yang tidak terinspirasi, merupakan situasi yang tiba-tiba muncul dan secara tidak langsung dapat merubah minat beli konsumen (Kotler dan Keller, 2013:137).

Minat beli merupakan kecenderungan konsumen untuk membeli suatu merek atau mengambil tindakan yang berhubungan dengan pembelian yang diukur dengan tingkat kemungkinan konsumen melakukan pembelian (Assael, 2001).

\section{Kerangka Pemikiran}

Berdasarkan uraian yang telah dikemukakan di atas secara sistematis model kajian pustaka dalam penelitian ini dapat digambarkan sebagai berikut:

Gambar 1. Kerangka pemikiran

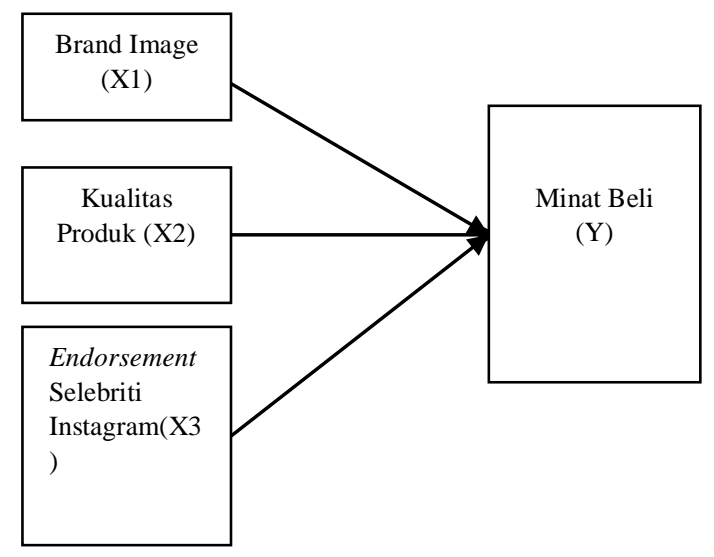

Gambar 1. Kerangka Penelitian

\section{Pengembangan Hipotesis}

\section{a. Pengaruh Brand Image Terhadap Minat Beli Konsumen}

Citra menurut Kotler dan Keller (2011:258) adalah sejumlah keyakinan, ide, dan kesan yang dipegang oleh seseorang tentang sebuah objek. Brand image dapat terbentuk melalui brand associationsdalam diri konsumen.Menurut Keller (2013:122) ada tiga faktor yang membentuk brand associations yaitu; Strength of Brand Associations (bagaimana melalui pengalaman, sebuah brand dapat dengan kuat menancap dalam diri konsumen dan mempengaruhi mereka), Favorability of Brand Associations (bagaimana pemasar meyakinkan konsumen bahwa sebuah 


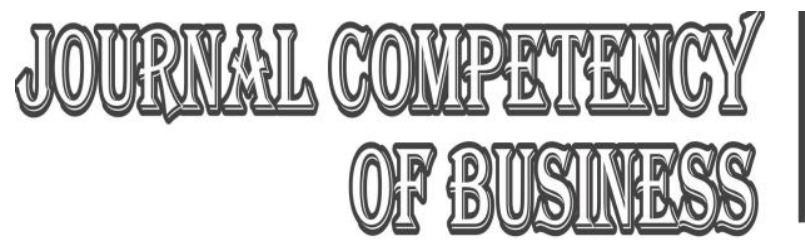

Fakultas Ekonomi, Universitas Cokroaminoto Yogyakarta

merek dapat mengandung atribut dan keuntungan yang relevan untuk dapat memenuhi kebutuhan dan keinginan mereka), dan Uniqueness of Brand Associations (bagaimana sebuah brand memiliki keunggulan kompetitif yang sustainable sehingga konsumen memiliki alasan tersendiri untuk membeli sebuah produk).

Dalam penelitian sebelumnya, Mendrika (2017) menyatakan bahwa brand image beerpengaruh terhadap minat beli ulang dan berpengaruh positif. Oleh karena itu perusahaan perlu meningkatkan brand image agar mendorong terhadap minat beli konsumen.

H1: Brand Image berpengaruh positif terhadap minat beli pada produk skin care MS GLOW.

\section{b. Pengaruh Kualitas Produk Terhadap Minat Beli Konsumen}

Kualitas produkmemiliki peran yang sangat penting dalam menarik minat beli konsumen. Karena apabila kualitas produknya baik maka akan mengurangi minat beli konsumen. Sedangkan apabila kualitas produktersebut baik maka akan semakin menari minat beli konsumen. Kualitas produk sering kali digunakan konsumen sebagai patokan untuk membeli suatu barang.

Dalam penelitian sebelumnya, Satria (2017) dalam penelitiannya tentang pengaruh harga, promosi, kualitas produk terhadap minat beli menyatakan bahwa kualitas produk berpengaruh secara signifikan terhadap minat beli.

$\mathrm{H} 2$ : Kualitas produk berpengaruh positif terhadap minat beli pada produk skin care MS GLOW.

\section{c. Pengaruh Endorsement Selebriti Instagram Terhadap Minat Beli Konsumen}

Celebrity endorsement digunakan untuk menarik perhatian khalayak serta diharapkan mampu meningkatkan awareness produk. Penggunaan celebrity endoser menimbulkan kesan bahwa konsumen selektif dalam memilih dan meningkatkan status dengan memiliki apa yang digunakan oleh selebriti (Pradhan , 2014). Celebrity Endorsement adalah advertising yang cukup umum untuk 


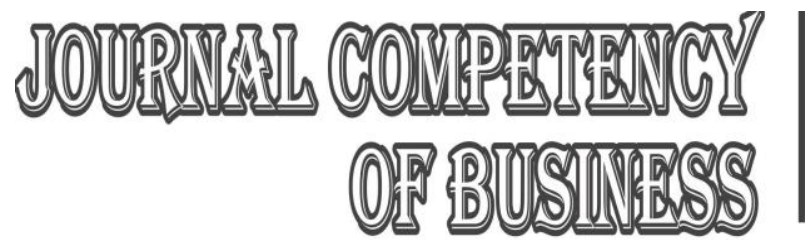

Fakultas Ekonomi, Universitas Cokroaminoto Yogyakarta

melakukan promosi melalui aso-siasi eksplisit dengan menggunakan selebriti, produk kosmetik, produk jam tangan, alcohol, mobil, apotek, program penurun berat badan, dan jasa keuangan dengan tujuan meningkatkan Brand Awareness (Garthwaite, 2014:76).

Seorangan selebriti instagram atau sering disebut selebgram itu biasanya orang-orang yang mampu menarik minat beli konsumen pada produk yang dia promosikan atau endorse. Semakin kreatif seorang selebgram untuk mempromosikan barangnya atau mengendors barang tersebut makan akan semakin banyak konsumen yang berminat untuk memberi barang yang mereka endorse.

Dalam penelitian sebelumnya, Anggraini, dkk (2018) dalam penelitiannya tentang pengaruh endorsement beauty vlogger terhadap minat beli menyatakan Pengaruh endorsement beauty vlogger terhadap minat beli berpengaruh signifikan.

H3: Endorsement selebriti instagram berpengaruh positif terhadap minat beli pada produk skin care MS GLOW.

\section{d. Pengaruh Brand Image, Kualitas Produk, dan Endorsement Selebriti Instagram Terhadap Minat Beli Konsumen}

Dalam penelitian sebelumnya, Syamsurizal dan Ernawati (2020) menyatakan bahwa brand image berpengaruh positif terhadap minat beli konsumen. Satria (2017) dalam penelitiannya bahwa kualitas produk berpengaruh signifikan terhadap minat beli konsumen. Mubarok (2016) dalam penelitiannya menyatakan bahwa celebrity endorsement berpengaruh pada minat beli konsumen.

H4: Brand Image, kualitas produk dan Endorsement selebriti instagram berpengaruh positif terhadap minat beli pada produk skin care MS GLOW. 


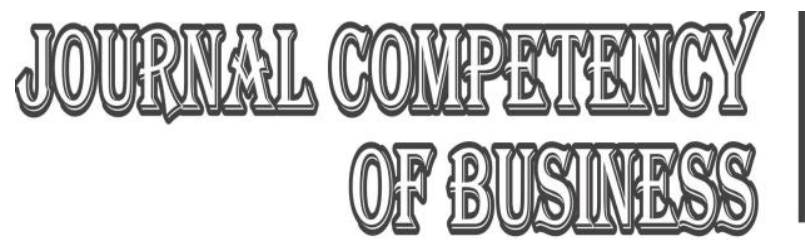

Fakultas Ekonomi, Universitas Cokroaminoto Yogyakarta

\section{Metodologi Penelitian}

\section{Metode Penelitian}

Penelitian ini termasuk dalam ikategori penelitian Kuantitatif dengan metode survei. Sugiyono $(2017,23)$ Menyatakan metode survei adalah metode kuantitatif karena data penelitian berupa angka-angka dan analisis menggunakan statistik. Dinamakan menitik beratkan pada pengujian hipotesis dengan menggunakan data terukur sehingga diharapkan dapat ditarik kesimpualan. Digunakan untuk meneliti pada populasi atau sample tertentu, pengumpulan data menggunakan instrumen penelitian, dengan tujuan untuk menguji hipotesis yang sudah ditetapkan.

\section{Populasi dan Sampel}

\section{a. Populasi}

Populasi dalam penelitian ini adalah pengguna scarlett whitening dan pengikut (follower) Instagram scarlett whetening dengan jumlah 4,1 juta follower pada bulan Maret 2021.

\section{b. Sampel}

Jumlah sampel dari penelitian ini adalah 100 orang. Teknik yang digunakan dalam penelitian ini adalah simple random sampling. Dikatakan simple (sederhana) karena pengambilan anggota sampel dari populasi dilakukan secara acak tanpa memperhatikan strata yang ada dalam populasi itu. Cara demikian dilakukan bila anggota populasi dianggap homogen (Sugiyono, 2017:140). Maka penentuan sampek menggunakan rumus dari (Sugiyono, 2017:137) sebagai berikut:

$$
n=\frac{N}{1+N e^{2}}
$$


Fakultas Ekonomi, Universitas Cokroaminoto Yogyakarta

Keterangan :

n : Ukaran Sampel

$\mathrm{N}$ : Ukuran populasi

E: Presen klongaran ketidakpastian karena kesalahan pengammbilan sampelyang masih dapat diteloransi atau diingginkan, misal 10\%

Dengan menggunakan rumus ditas, maka diperoleh perhitungan sebagai berikut :

$$
\begin{gathered}
n=\frac{18252}{1+18252(0,1) 2} \\
n=\frac{18252}{1+182,53}=99,99 \\
n=100
\end{gathered}
$$

Dari perhitungan diatas maka sampel digunakan dalam penelitian ini

\section{Teknik Pengambilan Sampel}

\section{a. Metode kuesioner}

Kuesioner dalam peneltian ini disebar melalui internet. Skala pengukuran kuesioner penelitian ini menggunakan skala likert yang sebahai berikut:

$$
\begin{array}{rlr}
\text { SS } & \text { : Sangat Setuju } & \text { (5) } \\
\text { S } & \text { : Setuju } & (4) \\
\mathrm{N} & \text { : Netral } & (3) \\
\text { TS } & \text { : Tidak Setuju } & (2) \\
\text { STS } & \text { : Sangat Tidak Setuju (1) } \\
\text { Penelitian } & \text { ini menggunakan skala likert dengan skor 1-5 agar } \\
\text { responden dapat memilih sesuai jawaban netral pada setiap kuesioner. }
\end{array}
$$


Fakultas Ekonomi, Universitas Cokroaminoto Yogyakarta

\section{Hasil Penelitian}

\section{Hasil Uji Asumsi Klasik}

\section{a. Multikoleniaritas}

Pengujian adanya multikolinearitas dilakukan dengan memperhatikan besarnya tolerance dan besarnya VIF (Suliyanto, 2011). Jika nilai tolerance > 0,10 atau $<1$ dan VIF $<10$, maka tidak terjadi multikolinearitas. Hasil uji multikolinearitas disajikan pada Tabel berikut :

Tabel 1. Hasil Uji Multikoleniaritas

\section{Coefficients $^{\mathrm{a}}$}

\begin{tabular}{|l|l|l|}
\hline \multirow{2}{*}{ Model } & \multicolumn{2}{|l|}{ Collinearity statistics } \\
\cline { 2 - 3 } & Tolerance & VIF \\
\hline Brand Image & 0,387 & 2,583 \\
\hline Kualitas Produk & 0,387 & 2,582 \\
\hline $\begin{array}{l}\text { Endorsement Selebriti } \\
\text { Instagram }\end{array}$ & 0,589 & 1,697 \\
\hline
\end{tabular}

a. .Dependent Variabel: Rata Y

Dari Tabel 1 dapat diketahui hasil perhitungan dengan menggunakan SPSS 24.0, menunjukan bahwa nilai tolerance $>0,10$ atau $<1$ dan VIF $<10$. Hal ini dapat disimpulkan bahwa persamaan model regresi tidak mengandung masalah multikolinieritas yang artinya tidak ada korelasi diantara variabel-variabel bebas sehingga layak digunakan untuk analisis lebih lanjut.

\section{b. Heterokedastisitas}

Heteroskedastisitas muncul ketika varian dari distribusi probabilitas gangguan tidak konstan untuk seluruh pengamatan atas variabel penelitian. Metode yang digunakan untuk menguji heteroskedastisitas dalam penelitian ini memakai diagram scatterplot. Hasil uji heteroskedastisitas disajikan pada gambar 4.2 berikut : 
Gambar 2. Hasil Uji Heterokedastisitas Scatterplot Dependent Variable: RataY

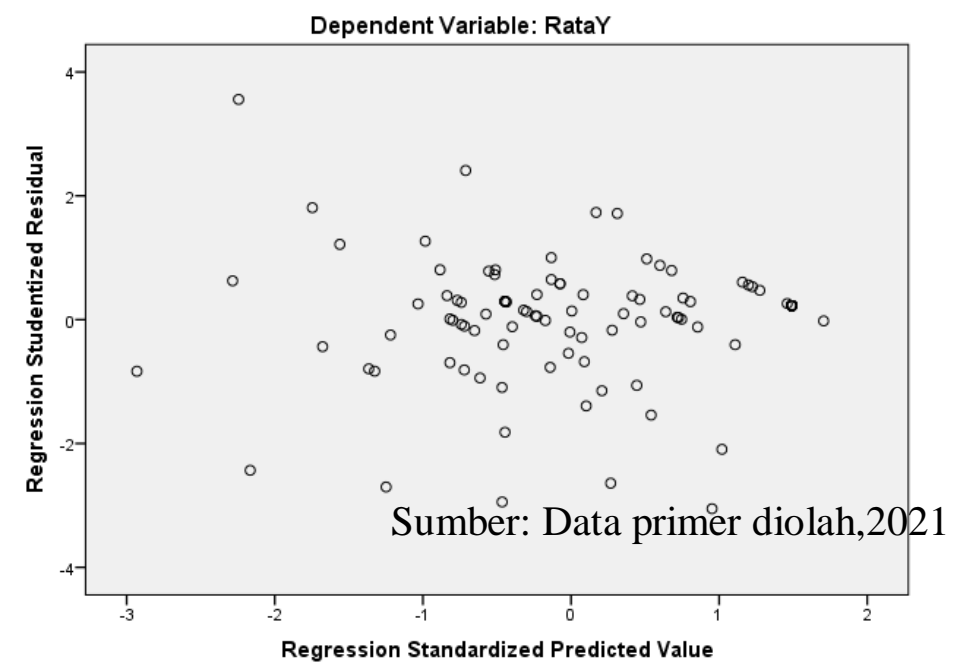

Berdasarkan Gambar 2 diatas dapat disimpulkan bahwa tidak ada pola yang jelas, serta titik-titik menyebar keatas dan dibawah 0 pada sumbu Y maka tidak terjadi heteroskedastisitas.

\section{Pengujian Hipotesis}

\section{a. Uji Signifikansi Parsial (t)}

Uji statistik $\mathrm{t}$ digunakan untk mengetahui pengaruh secara parsial variabel independen brand image, kualitas produk, endorsement selebriti instagram terhadap variabel dependen yaitu minat beli konsumen pada produk skin care MS GLOW. Untuk membuktikan pengaruh disetiap variabel independen terhadap variabel dependen dilakukan pada perumusan uji hipotesis. Hasil uji t-test dapat ditunjukkan pada Tabel 2. 


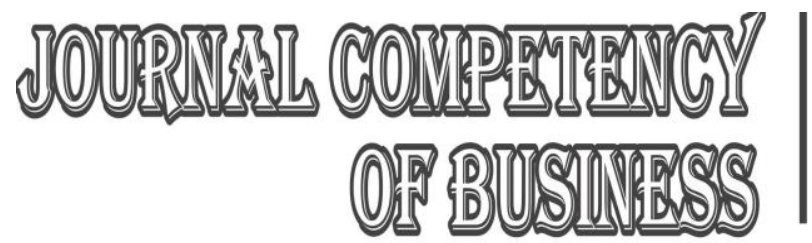

Fakultas Ekonomi, Universitas Cokroaminoto Yogyakarta

Tabel 2. Hasil Uji Signifikan Secara Parsial (t)

Coefficients $^{\mathrm{a}}$

\begin{tabular}{|c|c|c|c|c|c|}
\hline \multirow[t]{2}{*}{ Model } & \multicolumn{2}{|c|}{$\begin{array}{l}\text { Unstandardized } \\
\text { Coefficients }\end{array}$} & \multirow{2}{*}{$\begin{array}{l}\text { Standardized } \\
\text { Coefficients } \\
\text { Beta }\end{array}$} & \multirow[t]{2}{*}{$\mathbf{T}$} & \multirow[t]{2}{*}{ Sig } \\
\hline & B & Std.E & & & \\
\hline (Constant) &,- 738 & 0,444 & & $-1,663$ & 0,100 \\
\hline Brand Image & 0,547 & 0,153 & 0,386 & 3,570 & 0,001 \\
\hline Kualitas Produk & 0,576 & 0,156 & 0,399 & 3,689 & 0,000 \\
\hline $\begin{array}{l}\text { Endorsement } \\
\text { Selebrity } \\
\text { Instagram }\end{array}$ & 0,027 & 0,109 & 0,022 & 0,245 & 0,807 \\
\hline
\end{tabular}

Sumber: Data primer diolah,2021

Berdasarkan tabel 2 hasil uji-t test dalam penelitian ini sebagai berikut :

1. Pengaruh Brand Image terhadap minat beli konsumen.

H0 : Tidak ada pengaruh Brand Image terhadap minat beli konsumen.

H1 : Brand Image berpengaruh positif dan signifikan terhadap minat beli konsumen.

Berdasarkan dari hasil perhitungan yang ditunjukkan pada Tabel 4.10 di atas, diperoleh nilai p-value hasil uji-t dari variabel Brand Image sebesar 0,001. Dikarenakan nilai $p$ value lebih kecil dari tingkat signifikan $\alpha=5 \%$ atau $(0,001$ $<$ 0,05), maka H0 ditolak dan H1 diterima, yang berarti Brand Image berpengaruh positif dan signifikan terhadap minat beli konsumen.

2. Pengaruh Kualitas Produk terhadap minat beli konsumen.

H0 : Tidak ada pengaruh kualitas produk terhadap minat beli konsumen.

H2 : kualitas produk berpengaruh positif dan signifikan terhadap minat beli konsumen. Berdasarkan dari hasil perhitungan yang ditunjukkan pada Tabel 4.10 di atas, diperoleh nilai p-value hasil uji-t dari variabel Kualitas Produk sebesar 0,000. Dikarenakan nilai $\mathrm{p}$ value lebih kecil dari tingkat signifikan $\alpha=$ 
Fakultas Ekonomi, Universitas Cokroaminoto Yogyakarta

$5 \%$ atau $(0,000<0,05)$, maka $\mathrm{H} 0$ tolak dan $\mathrm{H} 2$ diterima, yang berarti Kualitas

Produk berpengaruh positif dan signifikan terhadap minat beli konsumen.

3. Pengaruh Endorsement Selebriti Instagram terhadap Minat Beli Konsumen.

H0 : Tidak ada pengaruh Endorsement Selebriti Instagram terhadap minat beli konsumen.

H3 :Endorsement Selebriti Instagram berpengaruh positif dan signifikan terhadap minat beli konsumen.

Berdasarkan dari hasil perhitungan yang ditunjukkan pada Tabel 2 di atas, diperoleh nilai p-value hasil uji-t dari variabel Endorsement Selebrity Instagram sebesar 0,897. Dikarenakan nilai $\mathrm{p}$ value lebih besar dari tingkat signifikan $\alpha=$ $5 \%$ atau $(0,897<0,05)$, maka H0 diterima dan $\mathrm{H} 3$ ditolak, yang berarti tidak ada pengaruh Endorsement Selebriti Instagram terhadap minat beli konsumen.

\section{b. Uji Signifikansi Simultan (f)}

Uji statistik F pada dasarnya menunjukkan apakah semua variabel bebas yang dimasukkan dalam model mempunyai pengaruh secara bersama-sama terhadap variabel terikat. Hasil uji F dengan menggunakan program SPSS 24.0 pada tabel 3 sebagai berikut:

Tabel 3. Hasil Uji Signifikansi Simultan (F)

ANOVA $^{\mathrm{a}}$

\begin{tabular}{|l|l|l|l|l|l|}
\hline Model & $\begin{array}{l}\text { Sum of } \\
\text { Squares }\end{array}$ & df & $\begin{array}{l}\text { Mean } \\
\text { Square }\end{array}$ & F & Sig \\
\hline Regression & 28,266 & 3 & 9,422 & 41,500 & $0,000^{\mathrm{b}}$ \\
\hline Residual & 21,795 & 96 & 0,227 & & \\
\hline Total & 50,061 & 99 & & & \\
\hline
\end{tabular}

a. Dependent Variabel : Minat Beli Konsumen

b. Predictors : (Constant), Brand Image, Kualitas Produk, Endorsement Selebriti Instagram

Sumber : Data Primer diolah, 2021 
Berdasarkan pada tabel 3 berikut formulasi hasil Uji F :

H0: Brand Image, Kualitas Produk, Endorsement Selebriti Instagramangan secara simultan tidak mempunyai pengaruh Minat Beli Konsumen.

H4 : Brand Image, Kualitas Produk, Endorsement Selebriti Instagram secara simultan mempunyai pengaruh terhadap Minat Beli Konsumen.

Berdasarkan dari hasil perhitungan yang ditunjukkan pada Tabel 3 di atas, diperoleh nilai $\mathrm{p}$ value dari hasil uji $\mathrm{F}$ sebesar 0,000 . Dikarenakan nilai $\mathrm{p}$ value lebih kecil dari tingkat signifikan $\alpha=5 \%$ atau $(0,000<0,05)$, maka Ha diterima dan $\mathrm{H} 0$ ditolak; yang berarti variabel Brand Image, Kualitas Produk, Endorsement Selebriti Instagram secara simultan mempunyai pengaruh terhadap Minat Beli Konsumen.

\section{Regresi Linear Berganda}

Analisis regresi linier berganda dilakukan guna mengetahui ada tidaknya pengaruh faktor variabel brand image, kualitas produk, endorsemen selebriti instagram terhadap variabel minat beli konsumen pada produk skin care MS GLOW. Uji analisis regresi linier berganda dalam penelitian ini dilakukan dengan menggunakan aplikasi SPSS untuk mempermudah dalam melakukan penelitian ini. Adapun hasil dari perhitungan analisis regresi linier berganda dapat dilihat pasa tabel berikut:

Tabel 4. Hasil Uji Regresi Berganda

Coefficients $^{\mathrm{a}}$

\begin{tabular}{|l|l|l|l|l|l|}
\hline \multirow{2}{*}{ Model } & \multicolumn{2}{|l|}{$\begin{array}{l}\text { Unstandardized } \\
\text { Coefficients }\end{array}$} & $\begin{array}{l}\text { Standardized } \\
\text { Coefficients }\end{array}$ & T & Sig \\
\cline { 2 - 4 } & B & Std.E & Beta & & \\
\hline (Constant) &,- 738 & 0,444 & & $-1,663$ & 0,100 \\
\hline Brand Image & 0,547 & 0,153 & 0,386 & 3,570 & 0,001 \\
\hline Kualitas Produk & 0,576 & 0,156 & 0,399 & 3,689 & 0,000 \\
\hline Endorsement & 0,027 & 0,109 & 0,022 & 0,245 & 0,807 \\
\hline
\end{tabular}


Fakultas Ekonomi, Universitas Cokroaminoto Yogyakarta

\begin{tabular}{|l|l|l|l|l|l|}
\hline $\begin{array}{l}\text { Selebrity } \\
\text { Instagram }\end{array}$ & & & & & \\
\hline
\end{tabular}

Berdasarkan Tabelmodel regresi berganda untuk Pengaruh Brand Image, Kualitas Produk, Endorsement Selebriti Instagram terhadap Minat Beli Konsumen Pada Produk Skin Care MS GLOWsebagai berikut :

Minat Beli Konsumen $=-, 738+0,547 \mathrm{BI}+0,576 \mathrm{KP}+$

$$
0,027 \mathrm{ESI}
$$

Dari persamaan diatas, dapat diinterpretasikan bahwa variabel Brand Image, Kualitas Produk, Endorsement Selebrity Instagram mempunyai arah koefisien regresi yang positif atau berbanding lurus terhadap minat beli konsumen, hal ini menunjukkan bahwa variabel Brand Image, Kualitas Produk akan memberikan pengaruh positif terhadap Minat Beli Konsumen. Sedangkan variabel, Endorsement Selebrity Instagrammempunyai arah koefisien regresi yang negatif atau berbanding terbalik terhadap Minat Beli Konsumen, hal ini menunjukkan bahwa Endorsement Selebrity Instagram memberikan pengaruh negatif terhadap Minat Beli Konsumen.

\section{Uji Koefisien Determinasi (R)}

Kualitas Produk, Endorsement Selebriti Instagram terhadap Minat Beli Konsumen maka digunakan koefisien determinasi berganda (Adjusted RSquare). Hasil koefisien deteminasi berganda dapat ditunjukkan pada Tabel 5 berikut :

Tabel 5. Hasil Uji Koefisien Determinasi (R)

Model Summary ${ }^{\mathrm{a}}$

\begin{tabular}{|l|l|l|l|l|}
\hline Model & $\mathbf{R}$ & R Square & $\begin{array}{l}\text { Adjusted } \\
\text { R Square }\end{array}$ & $\begin{array}{l}\text { Std Error } \\
\text { of the } \\
\text { Estimate }\end{array}$ \\
\hline 1 & $\mathbf{0 , 7 5 1 ^ { \mathbf { a } }}$ & $\mathbf{0 , 5 6 5}$ & $\mathbf{0 , 5 5 1}$ & $\mathbf{0 , 4 7 6 4 8}$ \\
\hline
\end{tabular}

a. Predictors : (Constant), Brand Image, Kualitas Produk, Endorsement Selebrity Instagram

b. Dependent Variabel : Minat Beli Konsumen 


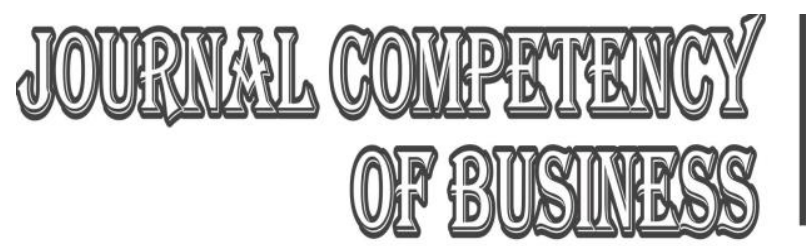

Fakultas Ekonomi, Universitas Cokroaminoto Yogyakarta

Dari Tabel 5 diatas dapat diketahui besarnya koefisien determinasi berganda (Adjusted $\mathrm{R}^{2}$ ) sebesar 0,551, maka dapat diartikan bahwa 55,1\% Minat Beli Konsumen dipengaruhi oleh ketiga variabel bebas yang terdiri dari Brand Image, Kualitas Produk, Endorsement Selebriti Instagram. Sedangkan sisanya sebesar 44,99\% dipengaruhi oleh variabel lain yang tidak dimasukkan dalam model penelitian.

\section{Pembahasan}

\section{Pengaruh Brand Image Terhadap Minat Beli Konsumen}

Brand image berpengaruh positif dan signifikan terhadap minat beli konsumen. Menurut Setiadi (2003: 180) citra merek (brand image) merupakan representasi dari keseluruhan persepsi terhadap merek dan dibentuk dari informasi dan pengalaman masa lalu terhadap merek itu.. Brand image ataupun citra merek pada umumnya adalah segala hal yang berkaitan dengan merek yang ada di benak konsumen. Hasil penelitian ini sejalan dengan penelitian terdahulu yang dilakukan oleh Mendrika (2017) menunjukkan bahwa Brand image mempunyai pengaruh terhadap loyalitas dan minat beli konsumen.

\section{Pengaruh kualitas produk terhadap minat beli konsumen}

Kualitas produk berpengaruh positif dan signifikan terhadap minat beli konsumen. Kualitas produk (product quality) didefinisikan sebagai evaluasi menyeluruh pelanggan atas kebaikan kinerja barang atau jasa Mowen dan Minor (2013). Hasil penelitin ini juga sejalan dengan penelitian terdahulu Yolanda (2020) menunjukkan bahwa kualitas produk berpengaruh signifikan terhadap keputusan pembelian.

\section{Pengaruh Endorsement Selebriti Instagram Terhadapa Minat Beli Konsumen}

Endorsement Selebriti Instagram tidak berpengaruh positif dan signifikan terhadap minat beli konsumen. Menurut Shimp (2000) yang di kutip dari Soesatyo dan Rumambi (2013:4) celebrity endorsement adalah penyampaian pesan tentang 


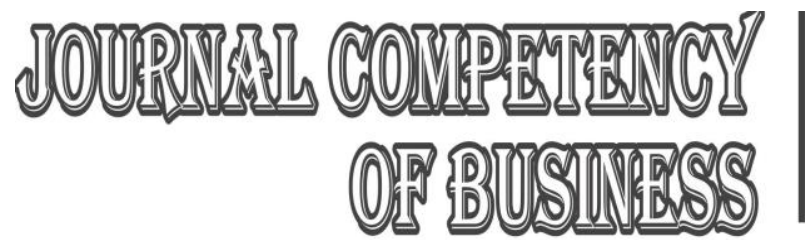

Fakultas Ekonomi, Universitas Cokroaminoto Yogyakarta

suatu jenis produk dengan menggunakan orang yang telah terkenal atau kalangan selebritis dengan tujuan untuk mempengaruhi orang lain karena prestasinya.. Hasil penelitin ini juga sejalan dengan penelitian terdahulu putri dan patria (2018) menunjukkan bahwa Endorsement Selebriti Instagram tidak berpengaruh terhadap minat beli konsumen.

\section{Kesimpulan}

Berdasarkan hasil penelitian pengaruh brand image, kualitas produk, endorsement Selebriti Instagram terhadap minat beli konsumen pada produk skin care MS GLOW dapat diambil kesimpulan sebagai berikut :

1. Berdasarkan hasil uji hipotesis secara bersama-sama (simultan) menunjukkan bahwa variabel independen yang meliputi brand image, kualitas produk, endorsement Selebriti Instagram terhadap minat beli konsumen pada produk skin care MS GLOW dengan nilai signifikansi 0,000 atau lebih kecil dari 0,05 .

2. Berdasarkan hasil uji hipotesis secara parsial :

a. Variabel brand image berpengaruh positif dan signifikan terhadap minat beli konsumen pada produk skin care MS GLOW dengan nilai signifikansi 0,001 atau lebih kecil dari 0,05.

b. Variabel kualitas produk berpengaruh positif dan signifikan terhadap minat beli konsumen pada produk skin care MS GLOW dengan nilai signifikansi 0,000 atau lebih kecil dari 0,05.

c. Variabel endorsement Selebriti Instagram tidak berpengaruh terhadap minat beli konsumen pada produk skin care MS GLOW dengan nilai signifikansi 0,807 atau lebih besar dari 0,05.

\section{DAFTAR PUSTAKA}

Adinda, Sakinah \& Endriana Pangestuti. (2019). Pengaruh Media Sosial Instagram @exploremalang Terhadap Minat Berkunjung Followers Ke Suatu Destinasi. Jurnal Administrasi Bisnis (JAB). Vol.72, No. 3. 
Fakultas Ekonomi, Universitas Cokroaminoto Yogyakarta

Adiwidjaja, Andrian junio \& Zeplin Jiwa Husada Tarigan. (2017 ). Pengaruh Brand Image dan Brand Trust Terhadap Keputusan Keputusan Pembelian Sepatu Converse. Agora. Vol. 5, No:3.

Anggraeni, Rima Dwi\& Edriana Pangestuti dkk. (2017). Pengaruh Endorsement Beauty Vlogger Terhadap Minat Beli Make Up Brand Lokal. Jurnal Manajemen dan Start-Up Bisnis. Vol. 2, No.1.

Audian, Dinda Septiani \& Roni Jayawinangun dkk. (2018). Pengaruh Celebrity Endorser Terhadap Minat Pembelian Produk Aidi.Id. Gadjah Mada Journal of Professional Psychology (Gamajpp) .Vol.4, No. 1.

Arora, Amishi dan Mrs Khushbu Sahu. 2013. Celebrity Endorsement: An effective Marketing Tool. Journal of Academic Research in Science, 1(2): 320-326.

Assael H, (2001), Consumen Behavior and Marketing Action, Edisi 3, Kent Publishing Company, Boston Massachusset,AS.

Durianto, Darmadi. 2003. Inovasi Pasar dengan Iklan yang Efektif: Strategi, Program, dan Teknik Pengukuran. Jakarta: PT. Gramedia Pustaka Utama.

Durianto, D. dan Liana, C. 2004. Analisis Efektivitas Iklan Televisi Softener Soft \& Fresh di Jakarta dan Sekitarnya dengan Menggunakan Consumen Decision Model. Jurnal Ekonomi Perusahaan 11 (1): 35-55.

Ferdinand, Augusty Tae. 2006. Metode Penelitian Manajemen. Semarang. Basan Penerbit Universitas Diponegoro.

Ghozali, Imam (2011). Aplikasi analisis multivariate. Badan penerbit Universitas diponorogo. Semarang.

Garthwaite CL. 2014. Demand Spillovers, Combative Advertising, and Celebrity Endorsement. American Economic Journal: Applied Economics, 6(2): 76104.

Keller. (2003). How To Manage Brand Equty. Jakarta: gramedia pustaka.

Keller, K.L. (2013). Strategic brand management: building, measuring, and managing brand equity (4th ed.). England: Pearson Education, Inc. 